\title{
MARKETING SYSTEM OF FRESH FRIUT ANDA VEGETABLE: THE ROLE OF MODERN AND WHOLESALE MARKET IN JAKARTA AND THE VICINITY
}

\author{
Togar A. Napitupulu \\ Jurusan Manajemen, Fakultas Ekonomi dan Bisnis, Universitas Bina Nusantara, \\ Jln. K.H. Syahdan No. 9, Palmerah, Jakarta Barat 11480 \\ tnapitupulu@binus.edu
}

\begin{abstract}
Marketing system of fresh fruits and vegetable in the context of the rapidly growing dynamic markets in Jakarta and the vicinity was studied. Unstructured interviews and observations of key persons, and panels were conducted, primarily in three main wholesale markets in Jakarta and the vicinity and some supermarkets. It was found that the availability of management services and associated facilities are not yet fully compatible with modern markets. Their role, therefore, in catering to the supermarkets is limited, in particular for vegetables due to requirements on quality and delivery schedules. In general, supermarkets procure their supply directly from production centers through special/dedicated suppliers, which currently amounts to about 1\% to 5\% of total production from production centers. If policy and conducive economic incentive are available, wholesale markets are not only domain of public investment anymore, but also private investments alike. The newly established wholesale markets show that they now have a higher rate of utilization than in the years before. It is therefore for the local government and the central government to furthers devise conducive policy and regulatory measures, and for the private to take this opportunity in terms of investment in developing the economy of the region.
\end{abstract}

Keywords: marketing system, modern market, wholesale market

ABSTRAK

Sistem pemasaran dari buah segar dan sayur dalam konteks dinamis pasar yang berkembang pesat di Jakarta dan sekitarnya itu dipelajari. wawancara tidak terstruktur dan observasi orangorang kunci, dan panel dilakukan, terutama di tiga pasar grosir utama di Jakarta dan sekitarnya dan beberapa pasar swalayan. Ditemukan bahwa ketersediaan jasa manajemen dan fasilitas terkait belum sepenuhnya kompatibel dengan pasar modern. Peran mereka, karena itu, dalam melayani supermarket dibatasi, khususnya untuk sayuran karena persyaratan kualitas dan jadwal pengiriman. Secara umum, supermarket mereka langsung mendapatkan pasokan dari sentra produksi melalui spesial / pemasok khusus, yang saat ini mencapai sekitar 1\% sampai 5\% dari total produksi dari sentra produksi. Jika kebijakan dan insentif ekonomi yang kondusif tersedia, pasar grosir tidak hanya domain investasi publik lagi, tapi juga swasta investasi sama. Pasar grosir baru didirikan menunjukkan bahwa mereka kini memiliki tingkat pemanfaatan yang lebih tinggi dari pada tahuntahun sebelumnya. Oleh karena itu untuk pemerintah daerah dan pemerintah pusat untuk lebih jauh dalam menentukan kebijakan yang kondusif dan regulasi, dan untuk swasta untuk mengambil kesempatan ini dalam hal investasi dalam pengembangan perekonomian daerah.

Kata kunci: sistem pemasaran, pasar modern, pasar grosir 


\section{INTRODUCTION}

\section{Background}

Demand for high quality fresh fruits and vegetables is generally considered as increasing following the growth of population, increasing urbanization, changing tastes and preferences especially of the young new generation, and the increasing numbers of working couples. Taking this opportunity, on the marketing side, one observes the growth of efficient modern retailers (supermarkets and hypermarkets) in urban areas. These often operate with a supply chain management system enabling them to minimize procurement costs, which is required in the increasingly competitive sector.

As part of this change, recent literature and earlier studies on wholesale markets indicated that the role of wholesale distribution markets (Pasar Induk) is increasingly important. During the last decennium, many Terminal Agribisnis similar to Pasar Induk and Sub-Terminal Agribisnis (one which is closer to production centers) were established in many places throughout Java and out of Java some of them even with private investment. This trend follows examples of major cities in Europe, the US, and elsewhere, including those in Thailand and Malaysia.

Direct collection and distribution trade in fresh produce serves the traditional outlets (small local vegetable markets, door to door sellers and small to medium size groceries), while national supermarkets (Hero, Yogya, Superindo, etc.) invariably routed their produce directly in the late 1980s and in the early 1990s. In those days the total volume of FFV retailed through supermarkets was estimated at less than $5 \%$ of total consumption. Today, with many more supermarkets and an increase in the number of high-income consumers, the picture has changed. An informal estimate says that around $25 \%$ of total FFV goes to supermarkets. This estimate, however, needs to be confirmed.

With this background, this study on FFV wholesale markets was implemented. This report gives findings of a quick survey into the role of the Pasar Induk in Jakarta, Tangerang and Bekasi. This study is particularly directed to identify the current role of wholesale markets in traditional markets/modern outlets, and to formulate policy implications based on analysis of FFV distribution through the wholesale markets.

\section{Objectives}

The main objective of this study is to understand the dynamics of wholesale distribution markets of FFV. The specific objectives could be broken down as follows: To review the change of wholesale distribution markets overtime. To examine the efficiency and policy changes on wholesale distribution markets of FFV. To formulate policy implications of the current role of wholesale distribution markets of FFV.

\section{RESEARCH METHODS}

\section{Study Approach and Locations}

The study uses interviews and primary observations, including in-depth interviews of key persons, and panels. Roadside and gate checks were implemented with authorized staff. The study also makes use of previous studies on the role of wholesale markets (Pasar Induk). Estimations on 
proportions of flows of fresh produce to urban centers were made to have some understanding about the supply distribution of FFV, and the backward linkages towards the farming population.

Visits were made to the three main FFV destinations in Jakarta and the vicinity, i.e., Pasar Induk Kramat Jati (Jakarta), Pasar Induk Combating (Bekasi), and Terminal Agribisnis Tenah Tinggi (Tangerang). In addition, some wet markets and supermarkets in Jakarta were also visited. Openended interviews with consumers of FFV were conducted as well. It is important to note that the study took place in the dry season, in June 2007. Because production of FFV is highly seasonal the time of the survey does have a direct influence of both the types of fruits and vegetables coming to market, while the origin of FFV is by necessity also influenced.

\section{Data Collection}

The study uses field observations (primarily on quantities, qualities, packing, transport and specific produce) in addition to primary and secondary data collection. The latter was conducted using unstructured questionnaires through interview techniques. Key respondents were selected purposively. They included supply distributors, trader's association personnel, intermediate traders, FFV trading enterprises/retailers, personnel of market places. Research centers and local government offices were also visited and discussions with management personnel of these institutions proved most useful.

\section{RESULTS AND DISCUSSION}

\section{Produce Entering Jakarta and Their Origin}

The produce that enters the wholesale markets comes mostly from Java and some come from Off Java and imports. Vegetables come mostly from the high land of west Java such as Lembang, Cipanas, Pangalengan, Sukabumi, Garut and others. Sources from Central Java include the Dieng highlands, Magelang, Brebes, Tegal, etc. From East Java produce comes from places as far as Wates, Rembang, Ampenan, Banyuwangi, Wonosobo. Sources of origin from out of Java include Medan, Lampung, Bengkulu, and Padang.

In contrast to the vegetables, fruits come mostly from East Java and from Off Java. Apple for instance, is brought from Malang and imports; avocado, besides from Java, a substantial amount is from West Sumatra. Pineapple are trucked in from Palembang, and shipped from Ambon. Banana, besides from Java are also sourced from Lampung, Sumatra. Citrus/Orange fruits come from Medan, Padang, Pontianak besides from Jember, East Java and imported produce. Grapes come from Bali. Mangoes, in addition to Java, are also procured from as far as Sumbawa. Dukuh, durian and kedongdong come from Palembang, Jambi, Lampung and Padang West Sumatra.

It is striking to know that the further the producer centre is distance from Jakarta, the more they are likely to supply only one commodity. Inversely the closer a producer centre, the more diversified the supply pattern is. In addition, fruits are also imported, in particular those which are not grown suitably in the country such as grapes, apple, pears, and citrus. Citrus for example is imported from China, Australia and Pakistan. Apple is imported from USA, China, while grapes are imported from USA.

Inter-regional trade of FFV is mainly performed for fruits because of the intrinsic characteristics of tropical fruits: they can be kept fresh longer than vegetables. Transport is mostly done by truck, and traveling time varies between one to about three days. The only concern on such 
transportation is the safety of the commodities due to packaging quality and road condition. Another concern is the high cost of transportation due to gasoline high price and transaction costs along the road during the delivery.

Imports mainly include fruits, especially orange, apple, pear and grape from China. Other major countries exporting to Indonesia are Australia, USA, New Zealand and South Africa. Imports of fruits create benefits for traders and the demand on such imports is increasing. In the current global trade, transactions on such imported fruits are unavoidable. Consumer preference could be accounted for as one of the most influencing factors for consumers to make their decision to buy local or imported fruits. Quality and appearance of traded fruits become the tangible characters attracting the consumers. Domestic fruits, therefore, are in global competition and it is up to the producers only to decide whether they are strong enough to deal with the same produce in the markets.

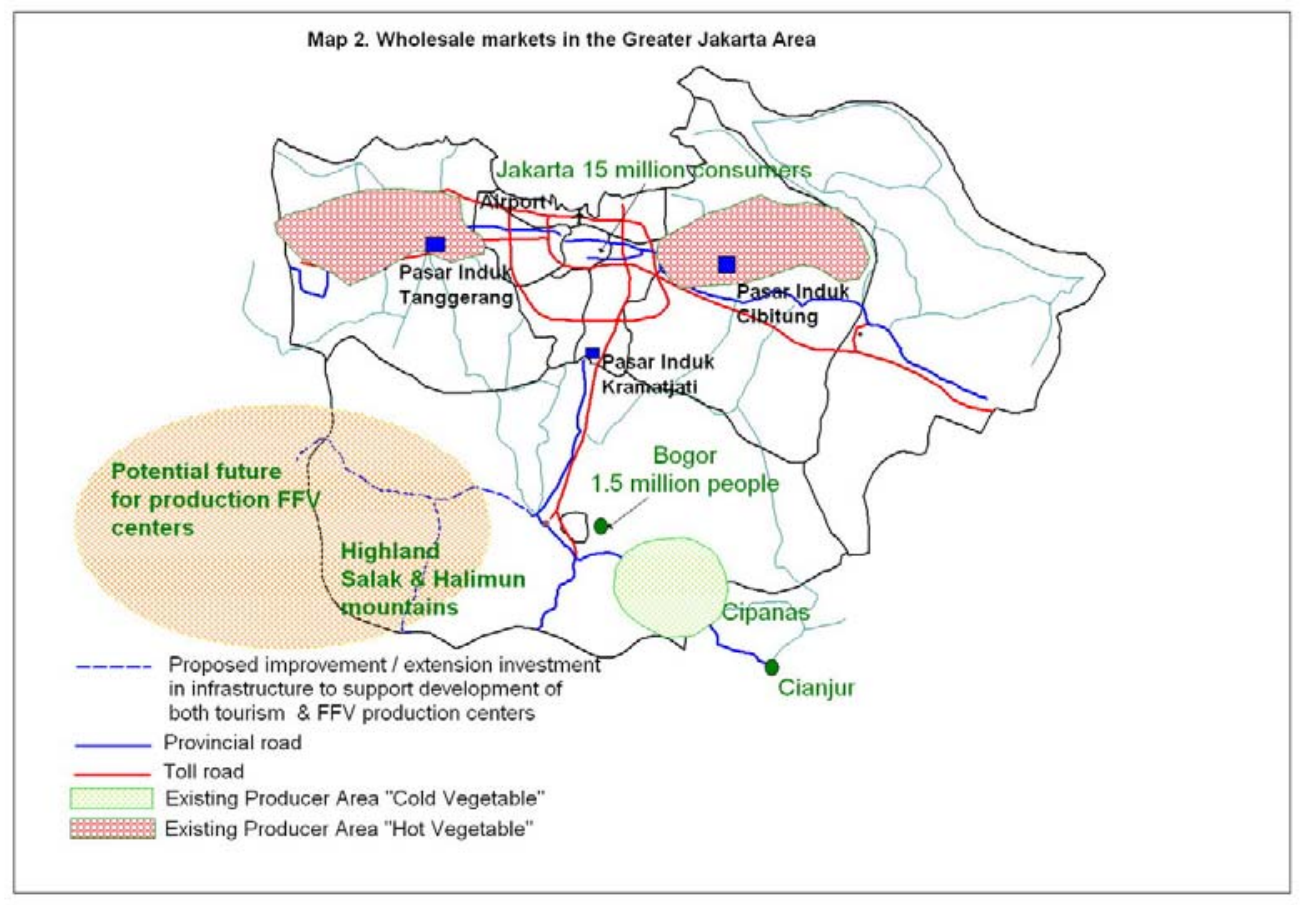

Figure 1 Wholesale Markets in the Greater Jakarta Area

\section{The Wholesale Markets}

\section{Recent History}

Pasar Induk Kramat Jati (PIKJ) was established in 1973, in the southern outskirt of Jakarta, having direct access to the Jagorawi toll road (See Map). Back then it was intended to cater to the whole total of retailer markets in the inner part of Jakarta and the vicinity. To achieve this objective, a governor regulation (No. D-V.a 18/1/17/1973, 23 December 1973) was enacted requiring that all truck loaded and bulky delivery of FFV to the inner part of Jakarta had to go through PIKJ. This system did not work well and traders sought to avoid the market. Expanded control attempts led to premanism, which in turn led to further avoidance. In 2003, the market was rejuvenated, and now has a total 4,648 kiosks of wholesalers and retailers and total 1,865 traders. The market is located in Jalan Raya Bogor, Km.17, Jakarta Timur, Kramat Jati, with a total area of 14.7 ha. 
Ten years after the establishment of PIKJ, another pasar induk in Cibitung, Bekasi West Java province was established, i.e., in 1984, right in the eastern outskirt of Jakarta, also having direct access to another toll road connecting Jakarta and Cikampek which was built after the consttruction of the toll road Jagorawi. It was not designed as wholesale market but as a redistribution centre for agricultural products including FFV (Hayami et al., 1991). Even though it is located in West Java, the regulation to not allow bulky/large truck delivery of FFV to inner Jakarta from this market was also applicable.

Both these markets were established and run by the government. It was not clear whether the establishment of Cibitung wholesale market was initiated by the West Java province independent of Jakarta, for example, just to serve city of Bekasi. It is most likely though that it was jointly planned by both provincial government, that is, in addition to serve the city of Bekasi, also to serve the eastern part of Jakarta.

In 2001, in line with the establishment of the toll road connecting Jakarta and Merak in the western outskirt of Jakarta, in the city of Tangerang Province of Banten (Formerly part of West Java Province) another wholesale market for FFV with direct access to the toll road was established purely with private investment by PT. Selaras Griya Adigunatama.

The rationale behind the establishment was that Jakarta as the capital city of the country needs another wholesale market for the smooth marketing and distribution of FFV through distribution centers, procurement centers, wholesale and retail centers to the smaller wholesale markets, retailers, and on to the consumers throughout the city. This in itself is considered to bring productivity growth to both local and regional economy. In addition, the establishment of the market also is expected to reduce organic garbage through out the inner city as no bulky and truck loaded FFV were allowed to enter the inner city. All the 151 retailers and smaller wholesale markets around the city and some others in the vicinity of Jakarta were only allowed to procure FFV from the three wholesale markets.

Some of the facilities provided by the market are physical marketing and trading infrastructures, general facilities, unloading and loading facilities, record keeping and other administrative facilities (Table 1). Trucking services are also available from the market to the various inner city markets organized by a cooperative having 1200 fleet of trucks. Recently, they have provided 29 agro outlets, which are expected to be rented by provinces to represent their agro-produce in the market.

It is not clear since when the new development in the distribution of FFV to the inner Jakarta has evolved, but it is likely to have started from the establishment of PIKJ. Now direct delivery from sources to inner city wholesale/retail markets is commonly observed. Not only to the wholesale/retail markets, but also direct delivery to hotels, restaurants, and hospitals is now common. Furthermore, with the fast growing of supermarkets/hypermarkets in Jakarta and vicinity, many of them are also procuring directly from the sources. Our conjecture is that due to a high quality and safety/hygiene requirements, many of these supermarkets are procuring FFV from special suppliers/vendors having their own farm or collecting from selected farmers. They deliver the produce, after some imposition of quality requirements, grading as well as sorting, directly to the supermarkets and hotels and restaurants. Nevertheless, some supermarkets and hotels and restaurants procure FFV from the wholesale markets through specialized suppliers.

Another development in the FFV markets is the growing volume of imports, in particular fruits such citrus, apples, and grapes and some fruits which are not grown in the country, and presumably some of the high quality vegetables demanded by hotels and restaurants which are also sold through the supermarkets. This importation is conducted by special importers and distributed to the various retailers and wholesalers, including the major wholesalers such as PIKJ. 
Table 1 Availability of Services and Capacity of the Three Wholesale Markets

\begin{tabular}{llll}
\hline \multicolumn{1}{c}{ Description } & \multicolumn{1}{c}{ PIKJ } & \multicolumn{1}{c}{ PI-Cibitung } & \multicolumn{1}{c}{ PI-Tangerang } \\
\hline $\begin{array}{l}\text { Volume of flow through: } \\
\text { Vegetables }\end{array}$ & 1400 tons/day & 2565 tons/day & $\begin{array}{l}1500 \text { tons/day }-2000 \\
\text { tons/day } \\
\text { smaller }\end{array}$ \\
Fruits & $\begin{array}{l}\text { 1500 tons/day } \\
\text { FFV:1835 }\end{array}$ & $\begin{array}{l}1710 \text { tons/day } \\
1830\end{array}$ \\
Retailing:1818 & & 1500 \\
Number of stalls & $\begin{array}{l}\text { Free purpose: } 890 \\
\text { General stores: } 76\end{array}$ & & 800 \\
Number of traders & 1865 & 7 units, mainly for fruits & $\begin{array}{l}5 \text { units, mainly for } \\
\text { fruits }\end{array}$ \\
\hline
\end{tabular}

\section{Kramat Jati Wholesale Market}

As was mentioned earlier, Kramat Jati wholesale market (PIKJ) was built and inaugurated on 28 December 1973. It is located in the southern part of Jakarta on Jalan Raya Bogor Km. 17, Jakarta having access to the toll road connecting Bogor/Puncak and Jakarta. The market is built in an area of total to 14.7 ha owned by the government of Jakarta province. Eventhough it is owned by the government of Jakarta, in the past several years starting 2002 as opposed to its early establishment, like all govenment owned company, it is now privately like run company.

After 2002, in addition to its main function as FFV wholesale market with 1,835 kiosks, it now provides retailing sevices for various products such as spices, processed food and others, with 1,818 kiosks. Besides those kiosks, there are also 890 spaces for free purposes and 76 general stores. There are 31 type of fruits and 37 type of vegetables sold in the market. On average, 1400 tons per day of vegetables goes through the market and around 1500 tons per day of fruits.

Unlike during its earlier time, our observation indicate that the wholesale market is now relatively eficiently operated catering to the surrounding wet markets and street vendors in the southern part of Jakarta. There is now only official retribution/fee charged to the traders compared to the many fees - official and unofficial - in former days. Pricing also is transparant, that is, in addition to the officially announced by the management, traders can always acquire price information through the widely available and used service of SMS.

In addition to catering to most wet markets in the surrouding area, the market also is a source of fruits to some supermarkets in the area. Some dedicated suppliers procure the fruits from the market and deliver them to the supermarkets. In addition to the supermarkets, these suppliers (around 10 of them) also provide fruits regularly to many growing specialized fruits outlet in the city. In our interview we found out that none of the vegetables were supplied to any of the supermarkets around the city. One particular reason why this is so, is due to the strict quality requirement on vegetables imposed by the supermarkets while most of the vegetables in the market are very poorly graded and still relatively dirty in the absence of sanitary and phytosanitary facilities. Fruits can be graded on the spot in the market without the need of sanitary facilities. It is worth mentioning here that the market does not have cold storage facility.

\section{Cibitung Wholesale Market}

Wholesale market Cibitung is located in the eastern outskirt of Jakarta in the cibitung exit of the toll road Jakarta-Cikampek. It is in Jalan Teuku Umar 1, Cibitung, Bekasi West Java province. As was mentioned earlier, it was established ten years later after Kramat Jati wholesale market, i.e., in 1984, in connection to the establishment of the toll road. It is owned and run by the West Java 
Regency of Bekasi government. The market is a lot smaller in size compared to Kramat Jati, that is, it houses only 1,830 stalls (kiosks). However, the amount of vegetables and fruits that goes through the market per day is larger than Kramat Jati, that is, 2,565 tons/day and 1,710 tons/day respectively; so its usage is more intensive.

Just like Kramat Jati, this market sources the vegetables and the fuits from various places in Java and Sumatra. In addition to tropical fruits, traders also import fruits during off seasons and some non-tropical fruits such as grapes, apples, citrus, and others. Traders from the surrounding wet markets and street vendors in the western part of Jakarta procure vegetables and fruits from this market. Interstingly however, some suppliers export vegetables which are procured from this market to Saudi Arabia after first grading and packing them in their packing house. Some are also supplying chili to Indofood Company, ginger to some Jamu (herbs \& spices) processors, and fruits to some supermarkets.

The market has seven units of cold storage which belong to one fruit trader. These cold stores facilitate fruit imports before they are redistributed to the various supermarkets, fruits shops, traditional wet markets, and street vendors. We do not have data on the trend of the fruits and vegetables flow through the market, but it is most likely that it is growing, catering to the growing urban population around Jakarta. This is in line also to the fact that establishment of this market was in response to the growing market and to cater to the population in the eastern part of Jakarta. Just like Kramat Jati market, Cibitung market also does not have phytosanitary facilities and over-all it relatively lags behind Kramat Jati in this respect.

\section{Tanah Tinggi Wholesale Market, Tangerang}

This market is located in the western outskirt of Jakarta in the Tangerang Regency, Banten Province, at Jalan Jenderal Sudirman, Tanah Tinggi, Tangerang. It was established in 2000 with direct access to the then newly built toll road Jakarta-Merak, connecting Jakarta and Lampung. Again, this occurred in response to the growing urbanization and to cater to the western outskirt of Jakarta. Notice that these last two wholesale markets are located not in Jakarta Province but in the neighboring Banten Province. The market is privately owned and run, the first such a market in Indonesia. This could indicate that private investment in wholesale markets is now lucrative enough while twenty or so years ago it was considered to belong to public investment domain. It is worth noting that the company that owns the market (PT. Selaras Griya Adigunatama) also built and operates another wholesale market in South Sumatra, Wholesale Market Jagaparing in Palembang. From the interview information, they are planning to also build similar markets in Bandung, West Java, Semarang, Central Java, Surabaya, East Java and Bali.

Earlier the market was designed to house FFV, meat and fish. But recently, in response to the demand trend, the meat and fish section were turned to facilitate FFV. There are 1500 stalls and five units of cold storage owned by some traders mainly for imported fruits. The amount of vegetables that flows through the market is around 1500 - 2000 tons/day while that of fruits is of smaller amount and seasonal. The sources of the produce are mainly from Java and some from North Sumatra and Kalimantan (citrus). In addition to the domestic fruits, a substantial amount of imported fruits also flows through the market, mainly citrus and apple from China.

\section{FFV Retail Markets}

There are several types of retail markets for FFV in Jakarta and the vicinity. First, they are the wet markets, supermarkets, fruits shops/groceries, peddlers and stalls/street vendors. The wet markets and fruit shops procure FFV from the wholesale markets and the surrounding production centers (in particular for hot vegetables such as kangkung, spinach, and other vegetables, and some fruits from the 
surrounding area such as banana). Most peddlers and some stalls and street vendors procure FFV from wet markets. Some other stalls/street vendors procure FFV directly from the wholesale markets.

\section{The Wet Markets}

Many of the wet markets in the country were established during the 60's and the 70's, including the 151 in the city of Jakarta under the presidential instruction (hence earlier the name of the markets were "pasar inpres" - presidential instruction market). The main objective then was to build market infrastructure as part of the economy infrastructure to facilitate the smooth and efficient marketing of the products in particular the back then mainly agricultural products and bringing them close to the then poor consumers. The total of these markets in Jakarta and the vicinity have gone up to three times the number since at least every sub-district has one "pasar inpres". Our estimates indicate that the flow of FFV from wholesale markets through the wet markets is around $95 \%$ of the total.

Recently, many of these markets have been renovated, in particular those which are in Jakarta to become modern "mall" type of market, where many goods are sold in the market from gold/silver apparels, clothing, books, consumer goods, processed foods, including FFV. In fact now direct retailing of FFV is only between $10 \%-20 \%$. There are three reasons why such an evolution occurred over time. First, with most of the markets now having been upgraded, and as a result of the continuous increase in price of land in the city, the price of stall in the market is very expensive beyond the ability of the small FFV traders to afford. Secondly, many of these facilities are relatively clean making it difficult for the FFV sellers to adjust to. Thirdly, an interesting evolution in the retailing of FFV is that the wet market is now a transitory place for FFV before it reaches the final consumers. Between 20:00 hours and 05:00 in the morning, peddler vendors, restaurants/food shops, stall/street vendors procure their FFV in the market usually not inside the market but along the streets around the market. This pattern can also be seen in the sleeper cities around Jakarta. This means that the word wet market is misleading. It may have applied in earlier decades, but right now they are actually open air low grade supermarkets or malls, offering a large variety of goods and services.

Most of the FFV are sold to consumers by peddlers who bring the produce, together with various products such as fish, meat, and spices, to the nearby housing complex and offer it from house to house, usually early in the morning. Purchase is done by the housewives or the maids. We can observe various kinds of transportation means being used from pushed carts, pedal carts, and motorcycles, up to small trucks. Our estimates are that this type of retailing sums up to about $50 \%$ of total produce. From our interviews we found out that none of the restaurants/warung procures the FFV from supermarkets and we estimate the flow to the restaurants to about $20 \%$ of total volume. One will also find stalls/street vendors (in front of a house or store) selling FFV. Our estimates FFV sold through this channel sums to about $10 \%$. The following table (Table 2 ) provides some insights on the price comparison of selected produce between wet market, peddler, and the supermarkets.

Table 2 Price Comparison of Selected Produce Between Wet Market, Peddler, and Supermarket

\begin{tabular}{lrrr}
\hline Produce & Wet market (Rp) & Peddler (Rp) & Supermarket (Rp) \\
Spinach & $500 /$ bunch & $750 /$ bunch & $2500 /$ bunch \\
Mustard green & $1000 /$ bunch & $1500 /$ bunch & $3500 /$ bunch \\
Broccoli & $10000 / \mathrm{kg}$ & $12000 / \mathrm{kg}$ & $25000 / \mathrm{kg}$ \\
Citrus & $5000 / \mathrm{kg}$ & $7500 / \mathrm{kg}$ & $12000 / \mathrm{kg}$ \\
\hline
\end{tabular}

\section{The Supermarkets}

A number of supermarkets were visited and some information collected. They are Hypermart, Super-Indo, Ramayana, and Carrefour. Several findings concerning FFV retailing through these 
markets are as follows. In general, the total amount of FFV sales relative to the total revenue is on average $5 \%$, with a small but growing proportion from vegetables. Most of the fruits are imported while most vegetables are procured domestically. There are several types of suppliers to the markets, first those who procure the produce (mostly fruits) from the wholesale markets and/or fruits importers/ wholesalers. Secondly are those who produce the vegetables themselves and having their own farm. Thirdly, those who procure the produce from the farmers having their own grading and packaging facilities. The last two types of suppliers are usually stationed close to production centers. Based on our interviews, none of the supermarkets so far procure the FFV directly from farmers. Some of these supermarkets do the importing themselves through their agency in the country of origin. Some others procure imported fruits from importing companies or from fruits suppliers who procure the fruits in turn from fruits wholesaler or from wholesale markets.

\section{Fruits Wholesalers}

Specialized fruits wholesalers usually wholesale store sell and distribute imported fruits. One particular fruits wholesaler, which was visited, was PT. Citra Segar, which is located in Jalan Tanah Merdeka, Pasar Rebo, Jakarta Timur. The company has been in operation during the past ten years. They have a large capacity cold room and nine-truck fleet. The company procures the products from ten importing companies in Tanjung Priok once they arrive and further store them in their cold room to be distributed later through-out the city. The fruits are oranges from China and Australia; apple from China and Australia; grapes from USA, Australia, China, and India; pears from China; longan from Thailand; durian from Thailand, and Malaysia; and citrus from Thailand.

Average daily imports (during its season) are 4 containers ( 1 container contains on the average 34 tons of produce). Buyers can buy directly from the storage site which what some suppliers to the supermarkets actually do. The company also has stalls/stores in the wholesale market Kramat Jati, and the other two wholesale markets. Average sales per day in Kramat Jati are around 40 tons.

\section{Issues in Urban Wholesale Marketing}

The produce that goes through these three wholesale markets is growing steadily. For example, there is a slight increase in total volume of vegetables that enters PIKJ from 1999 - 2006 and a relatively bigger increase in fruits for the same period (Figure 1 and 2). There is no data available for both PI Cibitung and PI Tangerang. However, in PI Tangerang two years after its establishment, occupation rate of the stalls was less than $40 \%$. But recently, occupation rate is above $95 \%$ (based on interview with management, 2007). Similarly we believe that PI Cibitung also experiences some increases in total sales of both vegetables and fruits. 


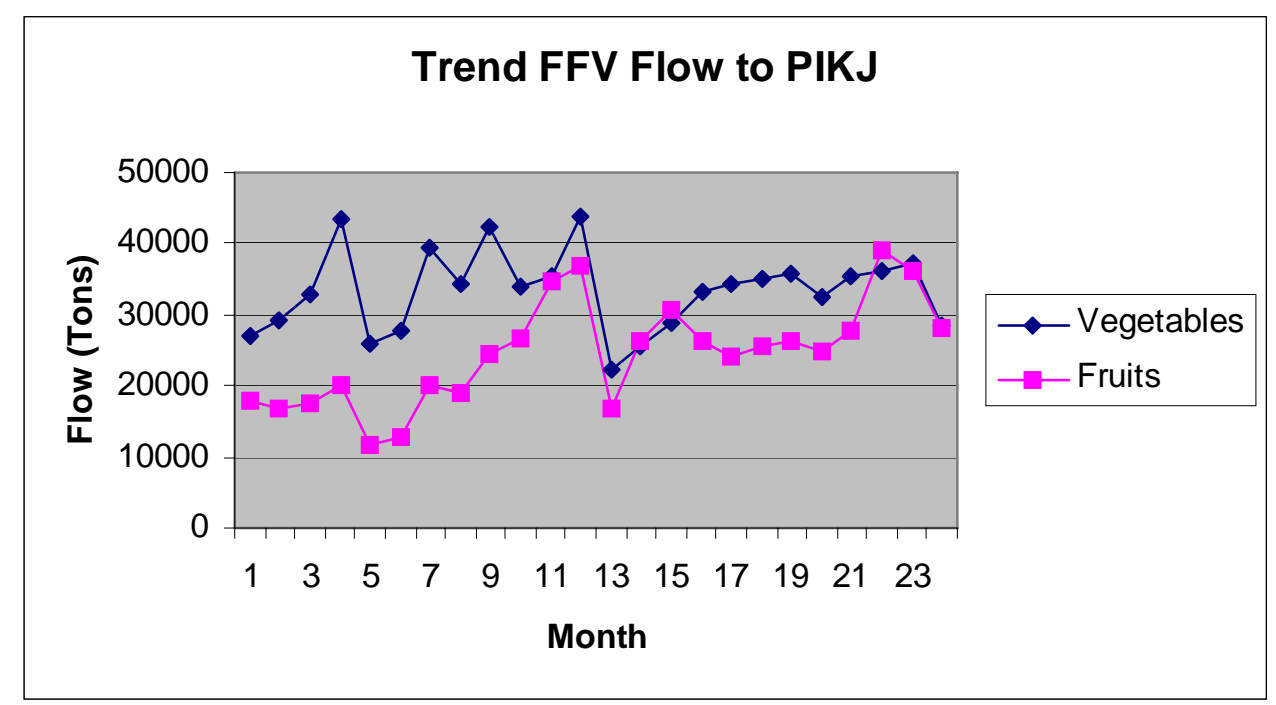

Figure 2 Trend of FFV Flow to PIKJ (1999 - 2000)

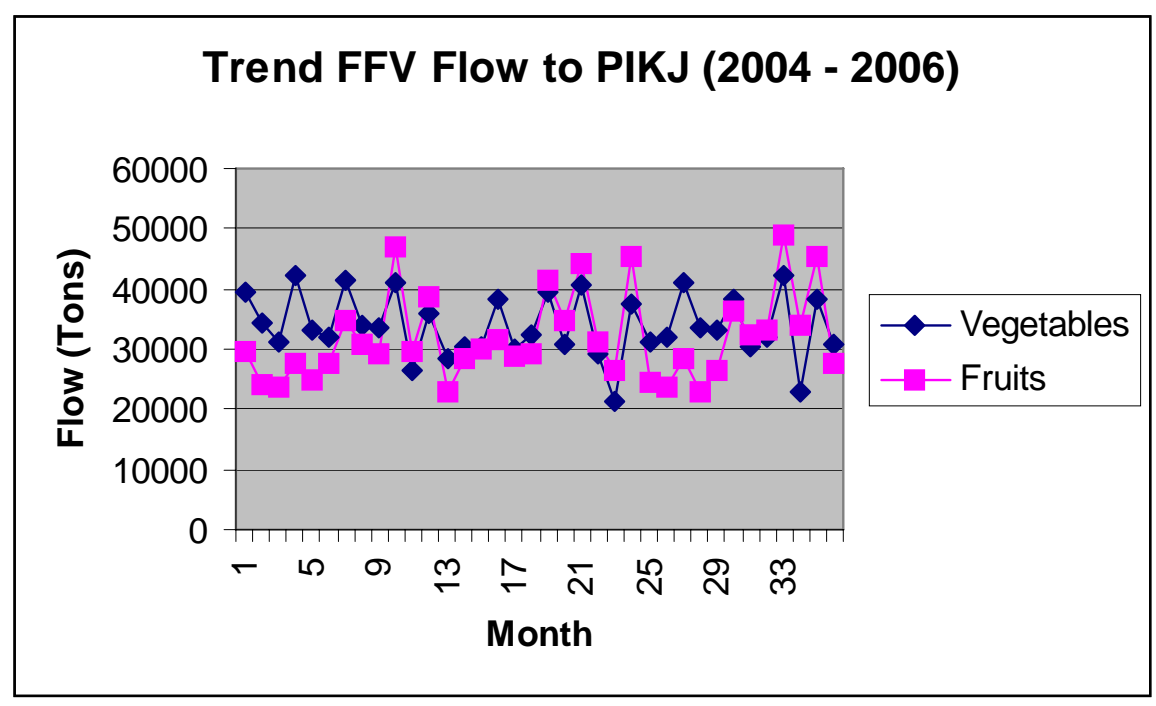

Figure 3 Trend of FFV Flow to PIKJ (2004 - 2000)

This findings should not be a surprise since the demand for both fruits and vegetables in Jakarta and the vicinity is increasing as the economy is steadily recovering from the crisis since 1999. There are strong reasons to believe that the rate of increase is even bigger prior to the crises in 1997.

The next question is to who do these wholesale markets cater to? Our findings indicate that the retailers in the around 151 wet markets in the inner city of Jakarta and the many wet markets in the vicinity of Jakarta such as Depok, Bogor, Bekasi, and Tangerang still procure FFV from either of the three major wholesale markets, dependent on the location and proximity to the wholesale markets. Dependent on the amount of delivery (usually smaller quantities) and the type of vegetables (for example cassava leaves), some of these wet markets procure from a distance wholesale markets such as Bogor but still not from production centers. There is an indication that some of the larger wet markets receive delivery from nearby production centers of relatively smaller loads.

Our conjecture that FFV now tend to directly go from production centers to the retailers and wet markets in the inner part of Jakarta avoiding PIKJ appears to be not completely true. It is true that 
in general supermarkets are directly procuring, in particular vegetables, from production centers through special suppliers, some are having their own farm and some are just traders, collecting the produce from farmers. Of those who have their own farm, some are also collecting the produce from the surrounding farmers through some kind of collaborations both involving technological and financial arrangements.

In addition to procuring directly from production centers, supermarkets are also receive delivery from suppliers who in turn procure the produce from wholesale markets. Currently there are about ten suppliers procuring the produce from PIKJ alone. Possibly for reasons of quality requirements and for lack of available sorting, grading and packaging facilities at PIKJ, most of the produce delivered to the supermarkets by these suppliers are fruits (note, sorting and grading vegetables are more difficult compare to fruits). This is true for the other two big wholesale markets, i.e., PI-Tangerang and PI-Cibitung. In addition to supplying to the supermarkets, the suppliers also deliver fruits to the many dedicated fruits outlet now around Jakarta and the vicinity.

To give us the picture on the role of supermarkets in catering FFV to the consumers around Jakarta and the vicinity, the following are some information from Hypermart, one of the largest supermarkets with domestic investment (PMDN). Hypermart now has outlets spread in many big cities or provincial capitals all over the country, even though mostly are in Jakarta and the vicinity. All operations on FFV are controlled from their distribution center, Menara Matahari Building Tangerang where PO are issued to suppliers and importers. Some of the delivery goes to their main cold storage warehouse in Cibitung Bekasi, and some delivered directly to the stores. Average sales of fruits of March and April 2007 was 1906.6 Tons, of which around 74.12\% were imported and $25.88 \%$ were supplied from domestic sources. This is about $5 \%$ of the total fruits that goes through PIKJ, where the domestic fruits is about $1 \%$.

Contrary to fruits, vegetables were mostly supplied from domestic sources, i.e., 72.74\%, compare to $27.26 \%$ imported. If we compare this figure with total vegetables that goes through PIKJ, this is about $1 \%$, where those that were supplied from domestic sources were about $0.7 \%$.

These finding were quite similar to the figures when we look at it from the production centers or from the source of origin. Suppliers and traders in Pangalengan, Cianjur and Lembang indicated that the percentage of vegetables sent to the supermarkets up to this day is around $1 \%$. They further stated that farmers in the production centers were flexible and able to adjust to the demand through both the traditional markets and the supermarkets. They argue that both demands are not affecting each others. Supply to the traditional markets continue to grow even though the demand from the supermarkets also growing

Many of the relatively larger wet markets in the inner city and the vicinity are both functioning as smaller wholesale and retail markets. They are wholesale markets because many street vendors and house-to-house peddler vendors procure the produce from these markets. One important development in the wet markets is that due to a sharp and lucrative increase in price of land and property in the inner city and the vicinity of Jakarta, many of the local town administration are tempted to improve the wet markets to a permanent mall type of facilities in the name of a cleaner, healthier and hygienic facilities to the society. This leads to skyrocketing prices of the stalls, which many vendors, in particular FFV vendors, can hardly afford.

Many multiple chain effects of such policy can be seen. First, it is expected that the price of vegetables faced by the many households, small restaurants, warung tegal (street food vendors), will go up. Hence the price of the consumers' cuisine will increase since the supply of vegetables to the surrounding area will be limited due to high price of the stall which will result in few if any at all vegetables stalls exist in the new improved market. Some of the stalls and some of the peddler vendors might still search for another affordable markets and locations but presumably at a relatively further 
distance resulting in increases in price. A further chain effect would be the raise in cost of food for the millions of low level workers in the vicinity of Jakarta in the absence of increase in wage. We have now observed an ad-hoc solution whereby the vegetables vendors/retailers are establishing their stall along the streets near the renewed market.

What is the implication of this new development in urban wholesale markets? It appears that improvement in urban wholesale and wet markets not so much a problem of investment, meaning availability of investors who are willing to invest in this venture. But it is a function of the change in land prices and space as well as the urban consumers behaviour, whether they are willing to pay for safer, cleaner, convenient, and higher quality FFV. To date, there is evidence toward this change in preferences, although it goes at a slow pace as can be seen in the limited sales of FFV by the growing number of supermarkets around the city. This growth is partly a result of the growing number of high income population of the city and the raise in average income per capita of the citizens. The mayority of the city population however, still prefers to shop for FFV in the wet markets or indirectly from peddlers through the wet market. This is in line with the finding of Nielsen survey (Jakarta post, April 2007). The argument that "as income increase and as more women enter the working market, moremore people will eat out, will prefer to shop once a week during the weeked and the best place to do that would be the supermarkets" is not completely true for the case of Indonesia at least for the time being, because practically the majority of the households in the city rely upon their maids to do the food preparation and hence the shopping of FFV which is mostly done through the peddler vendors.

One could therefore argue, that if any investment is contemplated, it should be to improve the the capacity and facilities of the wetmarkets and also the capability of the farmers to produce higher quality FFV, through modern farming technology and through improved post harvest and processing technology in the production centers. Such should be pursued in an evolutionised fashion, following the change in demand, not from the supply side. Investment in modern urban wet market facilities which force urban consumers to face the no alternative option with a consequences of a higher price/cost should be avoided.

It appeared from our interviews with the officials of the PIKJ and the Ministry of Agriculture that they do not agree with the opinion as proposed by some to improve the conditions of the wholesale markets to comply with the international standards of health and hygiene. Compliance with such international standards should be pursued in a holistic manner, that is, by taking into account the various aspects of the society, starting from culture, economic, social and education level, political and security aspects. For example, forcing a standard on a clean and hygiene wholesale and wet markets would be useless and in fact would possibly counter productive to development effort without first tending to improvement in income, provision of meaningful employment, improvement in education and culture which are all start at home.

We can observe at least one wholesale market in each city in the country even though not as big as the three found in Jakarta. However, these wholesale markets can be an embryo for future new modern wholesale markets in these cities as demand and the need of consumers and the number and income of urban population increases. Also many markets (they are referred to as "sub-terminal agribisnis") are now growing and established by the government and/or private near production centers around the country which in the future can be connected to the wholesale markets in the cities and the supermarkets.

\section{CONCLUSION}


Wholesale markets continuously play an important role in smoothing the flow of FFV from production centers to consumers in Jakarta and its vicinity. Over the years, wholesale markets are growing both in number, size, turnover and operational efficiency. The availability of management services and associated facilities are not yet fully compatible with modern markets.

Their role, therefore, in catering to the supermarkets is limited, in particular for vegetables due to requirements on quality and delivery schedules. In general supermarkets procure their supply directly from production centers through special/dedicated suppliers, which currently amounts to about $1 \%$ to $5 \%$ of total production from production centers. The total amount of FFV that flows through the wholesale markets to supermarkets is around $1 \%$ to $3 \%$. Supermarkets average percentage sales of FFV is less than $5 \%$ of total sales.

The wholesale markets and the wet markets are both an integral part of the urban distribution system, and they need to be analyzed together in terms of function and performance. The newly established wholesale markets show that they now have a higher rate of utilization than in the years before. That may be because they have been localizing functions on the basis of surrounding demand. There also may be a relation with privately managed operations. The whole greater Jakarta market system is organically growing, and wet markets may be the current constraint, in terms of hygiene, ease of use and space. There is pressure on the wet markets to convert into mall areas, which would especially affect the vast majority of consumers in Jakarta, with low expendable incomes.

The fast growing establishment of modern markets in urban areas in Indonesia is not directly affecting the traditional marketing chain of FFV distributed to traditional markets. The rapidly growing number of modern market outlets should be considered as additional market opportunity for FFV. Production centers continue their activities as usual although some efforts have been made by suppliers to consolidate FFV production collected from the farmers for sustainable distribution. Suppliers or intermediate traders (locals or inter-regionals) who do business with modern markets (Carrefour, Hypermart, Makro, Superindo, Yogya, Hero, etc.) are the most influencial marketing agents dealing with quality and continuity of FFV distribution, however, in terms of quantity, traditional markets are the prime destination of production centers.

Lastly, investment in the establisment of wholesale market is not immediately follows the growth in demand. It also requires availbility of the infrasructure such as roads and conducive policies. Furthermore, if policy and condicive economic incentive are available, wholesale markets are not only domain of public investment anymore, but also private investments alike.

With some 20 million consumers in a 40 by 50 kilometer square, having say two fifth of the total daily expenditure on food including fresh fruits and vegetables, is a huge economy that can not be undermined and taken lightly. This economy is very substantial indeed as we consider that this conglomeration employs in the supply chain hundreds of thousands of people in greater Jakarta, connecting the rural poor with urban consumers. As such, should not skip policy makers attention as a major opportunity for development.

In taking advantage of this opportunity and as this whole economy of Jakarta and the vinity is an integral part of the surrounding region and in fact to a certain extend the distace region, it is very important to take into consideration the autonomy of local government and their role in this development. This study brings out quite a few facts, among others the early willingness of provincial government to invest in FFV opportunities. The two new markets supplying Jakarta have been established with the support of the provincial government; this means that now there is a role for the local governments of the districts surrounding Jakarta. Obviously these need synergsim and to plan their future together. This include planning of a well connecting rural and urban infrastructure (roads, 
water, electricity and communications) which of course detailed local analysis will be necessary to make this possible.

\section{REFERENCES}

Agustian, A., A. Zulham, Syahyuti, H. Tarigan, A. Supriatna, Y. Supriyatna, and T. Nurasa. (2005). Analisis berbagai bentuk kelembagaan pemasaran dan dampaknya terhadap kinerja usaha komoditas sayuran dan buah (Marketing institution analysis and its impact on FFV performance). Pusat Penelitian dan Pengembangan Sosial Ekonomi Pertanian. Research Report, Bogor.

Bottema, et al. (2007). Vegetable production in West Java, Publication 100, CAPSA. Forthcoming.

Bottema, et al. (1989). Potato in Indonesia: Prospects for medium altitude production. Publication No 21. The CGPRT Center, Bogor.

Bottema, J. W. T., and K. Altemeier. (1989). Western Java in development perspective. Royan Institute of Linguistics and Anthropology. International Workshop on Indonesian Studies No. 4, Leiden, The Netherland.

Ferrari, Maria F. (1994). 20 years of horticulture in Indonesia: The vegetable subsector. Working Paper Publication No. 15. The CGPRT Center, Bogor.

Hayami, et.al. (1991). Marketing innovation for vegetables: Conditions of diversification in upland farming. Publication No.25. The CGPRT Center, Bogor.

Kusuma, et al. (1980). Price information service for vegetables in West Java, effects and impacts, findings of a survey conducted with 254 producers. Indonesian-German Technical Cooperation project ATA/85/86. Agricultural Market Information Service, publication no 8, Jakarta.

Reardon, T. (2004). The rise of supermarkets in Indonesia: Challenges and opportunities for smallholder farmers. In Natawidjaja, R.S., T.I. Noor, T. Perdana, and D. Supyandi: Case studies: the impact of supermarket growth on agricultural market development. Development Alternative Inc. and Center for Agricultural Policy and Agribusiness Studies, Bandung: Padjajaran University.

Saptana, E.L. Hastuti, et al. (2005). Pengembangan model kelembagaan kemitraan usaha yang berdayasaing di kawasan sentra produksi hortikultura (Institutional model development of business competitive partnership at horticultural production centers). Pusat Penelitian dan Pengembangan Sosial Ekonomi Pertanian. Research Report, Bogor.

World Bank Report. (2007). Horticultural producers and supermarket development in Indonesia. 